\title{
Performance of Corroding Steel Structure over Time
}

\author{
Swati Tikone $^{1}$, Priyanka Desai ${ }^{2}$, Karnika Jadhav ${ }^{3}$, Jayendra Bhosale ${ }^{4}$, \\ Mr.Manjunath. $\mathbf{M}^{5}$, Dr. Sharvil A Faroz ${ }^{6}$ \\ 1,2,3,4 (UG Students), 5 Assistant Professor, \\ Department of Civil Engineering, St John College of Engineering \& Management, Palghar. Maharashtra 401404 \\ ${ }^{6}$ Consultant, Infrastructure Risk Management, Mumbai, India, Pin:401202
}

DOI: 10.46335/IJIES.2020.5.7.3

\begin{abstract}
Corrosion of metals is one of the primary factors leading to the deterioration of bridge structures in the India. This study focus on the deterioration modelling by predicting the physical condition and performance assessment of steel girder by atmospheric corrosion and considering the effect of loading on this metallic girder. This atmospheric corrosion models are then presented, with the value given to exposure classification, with the Corrosivity classification guidelines, aimed at producing performance profile of element in metallic bridge girder. The result observe well with the empirical equation of the form $C=K t^{n}$, where $K$ and $C$ are the corrosion losses in micrometre and ' $t$ ' years of the exposure, respectively and ' $n$ ' is a constant. Based on ' $n$ ' value, the corrosion mechanisms for uncoated metals are predicted. And the corrosion deterioration of coated metal with the modified power formulation equation to consider the coating protection $C=K\left(t\right.$-to) $\wedge^{n}$, where 'to' exposure initiation time of coating and based on these value, the corrosion result for coated metals are predicted. Using two case studies, this study shows variation of the bending moment, shear force and deflection for that metallic girder. The result the study show that area loss due to increase of corrosion, then load carrying capacity of structure will decrease..
\end{abstract}

Keywords-Atmospheric corrosion; structure; performance; coating; bridge girder

\section{I- INTRODUCTION}

C orrosion is the natural process in which the material

is decayed caused by a chemical reaction with its environment. It is occurs when the exposure surface comes in contact with liquid and the process is accelerated by exposure warm temperature, acid and salt.in process of corrosion the chemical reaction take place in which iron combines with oxygen to form rust. The oxygen and water will completely converted the remaining iron to solid rust which is weak and flaky due to which the big holes in the metal are form. In engineering a structure is designed to ensure the durability of the structure However, during the service lifetime, often expose in the open year they are automatically subjected to atmospheric corrosion, as well as loading conditions such as dead load, live load, seismic loading plays a primary part in the deterioration of steel material in steel and RC structure.

The degradation of steel material due to atmospheric corrosion is of importance for the durability of the structure as a whole and may lead to structural damage accumulation and collapse eventually. If the accumulating damage cannot be timely detected, the structural safety will be threatened and the damage may finally cause the partial or whole collapse of the structure, resulting in have a significant impact with need of rehabilitation with economic lose and faculty casualty. The global studies have shown that the overall cost of corrosion amounts to at least $4-5 \%$ of the gross national product and that $20-25 \%$ of this cost could be avoided by using appropriate corrosion control technology. Several recent bridge collapses have been attributed to corrosion. In some cases, the highly damaged effects of corrosion go unheeded, with costly or even catastrophic results. In other cases, bridges are unnecessarily closed or replaced because their load carrying capacity cannot be determined. Iron corrosion in structure is important to investigate because corrosion 
can have a negative effect on the integrity of the structure and this can lead to catastrophic events.

\section{II- MODELING FRAMEWORK}

\subsection{Corrosion Model of Metal}

To describe the corrosion deterioration for a metal, corrosion growth (typically described in terms of corrosion penetration depth or thickness loss) is usually modeled as a function of time, $t$. Most corrosion models are formulated by the thickness loss refers to the average of the thickness losses of the metal In particular, the power formulation has been widely adopted which can be written as

$C t=\{0, t<$

$\left\{\theta o(t-)^{\theta 1}, t>\right.$ Where $\mathrm{C}(\mathrm{t})=$ amount of corrosion (e.g., the corrosion depth) at exposure time t;

$\mathrm{t} 0=$ corrosion initiation time;

$\theta \mathrm{o}=$ corrosion rate in the first year of exposure (since the initiation of corrosion); and

$\theta 1=$ coefficient that controls the rate of loss in subsequent years.

When using Eq. for corrosion on an uncoated metal, (to) is sometimes assumed to be 0 . Model parameters, $\theta$ o and $\theta 1$, are usually estimated using regression analysis on obtained under different atmospheric exposure conditions. Factors influence the selection of a coating system, such as the type and expected life of the bridge, the local climate and other environmental site Many conditions, the maintenance constraints, the surface preparation, the process used (spraying or galvanizing), and the

\subsection{Corrosion Study}

The aggressiveness of the atmospheric constituents can be assessed by measuring climatic and pollution factors or by determining the corrosion rate of exposed metals. This paper presents the data obtained in an experimental study of mild steel corrosion in different atmospheres during a 5-year exposure programme, at about 10 exposure stations located in different parts of India. The exposure station 8 (Mumbai) were classified as industrial area having heavy industrial manufacturing activities and other specific industrial emissions that were released from the sources located nearby.

Atmospheric conditions of Mumbai region was as follows
Table 1: Average Climatic Parameters

\begin{tabular}{|l|l|l|l|l|l|}
\hline $\begin{array}{l}\mathrm{N} \\
\text { o }\end{array}$ & $\begin{array}{l}\text { Locati } \\
\text { on }\end{array}$ & $\begin{array}{l}\text { SO2 } \\
\text { Depositi } \\
\text { on rate } \\
(\mathrm{mg} \mathrm{m}- \\
2 \mathrm{~d}-1)\end{array}$ & $\begin{array}{l}\text { chloride } \\
\text { Depositi } \\
\text { on rate } \\
(\mathrm{mg} \mathrm{m}- \\
2 \mathrm{~d}-1)\end{array}$ & $\begin{array}{l}\text { Corrosi } \\
\text { on rate } \\
\text { (CR,um } \\
\text { y-1) }\end{array}$ & $\begin{array}{l}\text { Corrosi } \\
\text { on } \\
\text { classifi } \\
\text { cation }\end{array}$ \\
\hline 1. & $\begin{array}{l}\text { Mumb } \\
\text { ai }\end{array}$ & 9 & 30 & 44 & $\mathrm{C} 3$ \\
\hline
\end{tabular}

Table no 2 : Average sulfur di oxide and chloride deposition rate

\begin{tabular}{|c|c|c|c|c|c|c|c|}
\hline $\mathrm{N}$ & Locatio & Type Of & \multicolumn{2}{|c|}{$\begin{array}{c}\text { Average } \\
\text { o }\end{array}$} & $\mathrm{n}$ & $\begin{array}{c}\text { Atmosph } \\
\text { ere } \\
\text { ure }\end{array}$ & \multicolumn{2}{|c|}{$\begin{array}{c}\text { Avg. } \\
\text { Relative } \\
\text { Humidity } \\
(\mathrm{RH} \%)\end{array}$} & $\begin{array}{c}\text { Avg. } \\
\text { Rainf } \\
\text { all } \\
(\mathrm{Mm})\end{array}$ \\
\cline { 4 - 6 } & & $\begin{array}{c}\mathrm{Mi} \\
\mathrm{n}\end{array}$ & $\begin{array}{c}\mathrm{Ma} \\
\mathrm{x}\end{array}$ & $\begin{array}{c}\mathrm{Mi} \\
\mathrm{n}\end{array}$ & $\begin{array}{c}\text { Ma } \\
\mathrm{x}\end{array}$ & \\
\hline 1. & $\begin{array}{c}\text { Mumb } \\
\text { ai }\end{array}$ & Industrial & 19 & 33 & 56 & 94 & 945 \\
\hline
\end{tabular}

\section{METHODOLOGY}

\subsection{Corrosion Analysis}

In this we have used the reduce thickness of the steel section for calculating strength of corroded steel.to compute various capacities of the section. Also we have workout corrosion profile for every 10 years from $0-50$ years. The variation of weight loss $(\mathrm{C})$ due to corrosion expressed as micro-metres $(1 \mathrm{~m})$ with time $(\mathrm{t})$ can be described by the general empirical equation in the form

$$
\mathrm{C}=\mathrm{K} \times \mathrm{t}^{\mathrm{n}}
$$

Linear regression analysis to fit straight line to a $\log -\log$ plot of corrosion loss (C) vs time ( $t$ ) in logarithmic form is done.

$$
\log \mathrm{C}=\log \mathrm{K}+\mathrm{n} \log \mathrm{t}
$$

Where $\mathrm{K}$ is the intercept (equal to the corrosion loss in first year) and ' $n$ ' is the slope of the log-log plot.

Both ' $\mathrm{K}$ ' and ' $\mathrm{n}$ ' are dependent on the type of metal and climatic parameters

From empirical kinetics equation of the form $\mathrm{C}=\mathrm{K}$ tn , where $\mathrm{K}$ and $\mathrm{C}$ are the corrosion losses in micromm and ' $\mathrm{t}$ ' years of the exposure, respectively, and ' $\mathrm{n}$ ' is a constant. Based on ' $n$ ' values, the corrosion mechanisms 
of these metals are predicted. To find out the value of $\mathrm{k}$ average corrosion rate of 5 years at exposure station was used.

Table 3: Avg. Corrosion Rate

\begin{tabular}{|l|l|}
\hline $\begin{array}{l}\text { Period of } \\
\text { exposure(year) }\end{array}$ & Corrosion rate \\
\hline 1 & 44.00 \\
\hline 2 & 26.72 \\
\hline 3 & 18.71 \\
\hline 4 & 16.70 \\
\hline 5 & 14.93 \\
\hline
\end{tabular}

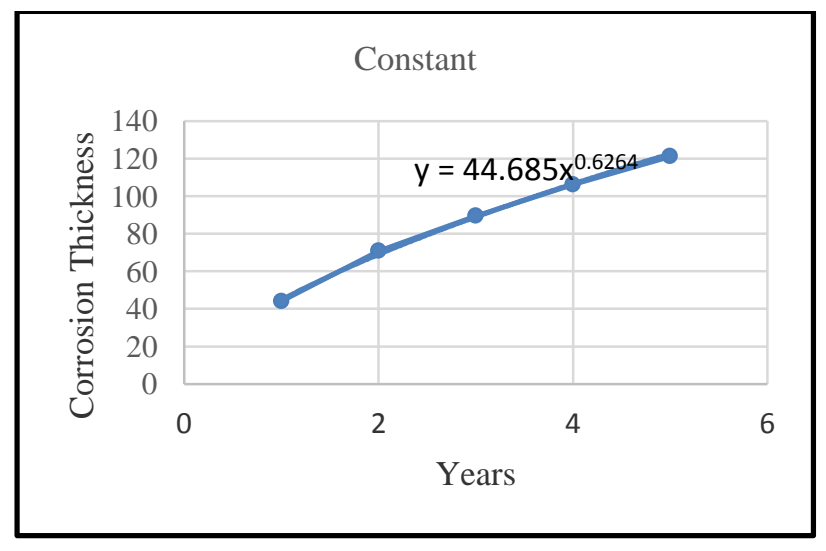

by solving the equations form using data from table no. 3 got the final corrosion equation as $\mathrm{C}=44.685 \mathrm{x} \mathrm{t} 0.6264$

Now the value of $\mathrm{k}$ and $\mathrm{n}$ were know and the only unknown was $t$ which is year of exposure.

Using this corrosion equation corrosion profile for every 5 years from $0-120$ years was workout. The study approach involves the calculation of bending moment capacity, shear capacity and deflection as per the formula recommended in code IS 800:7000. Permissible capacities of section was checked with present capacity of structure at every 5 years to know structural stability.

Permissible capacities of section was calculated by using externally applied load on the structure and maximum bending moment and shear force to be opposed by girder with respect to this externally applied load. If the bending moment capacity of corroded girder will be greater than maximum bending moment acting on it, then it will be safe i.e showing that structure will resist maximum bending moment and shear force acting on it.

Analysis of girder was done in two parts as part Afinding structural capacities for uncoated girder and part B - calculating structural capacities for coated girder i.e a layer of corrosion preventive chemical is applied on girder. Result are tabulate in table no 4 and 5. It was assumed that corrosion is uniform and root radius of section remains constant throughout the years not affected by corrosion. Also flange width of the section remains constant.

\subsection{Reduction In Thickness Of Coated Girder}

Paint is the most commonly used material to protect the steel from corrosion. Coating a metal surface with paint provides a barrier between the metal and the moisture in the environment. As steel begins to corrode, it thins and gradually loses strength. Paint system for steel structures have developed over the years to comply with industrial environmental legislation and in response to demands from bridge and building owners for improved durability performance. In this research paper we have use M27.4 coating system. The expected life if this coating is 5 to 7 years. The formula for calculation of corrosion thickness of coated girder is,

$$
\mathrm{C}=\mathrm{k} \times\left(\mathrm{t}-\mathrm{t}_{\mathrm{o}}\right)^{\mathrm{n}}
$$

The value of to is taken as 6 years, as the expected life of coating.

Table no. 4 description and expected service life of protective coatings

\begin{tabular}{|c|c|c|}
\hline $\begin{array}{l}\text { Coating } \\
\text { system } \\
\text { name }\end{array}$ & Description & $\begin{array}{l}\text { Expected } \\
\text { life } \\
\text { (years) }\end{array}$ \\
\hline M27.4 & $\begin{array}{l}\text { Protective system using bitumen. First } \\
\text { layer: surface tolerant epoxy primer (min } \\
\text { dft } 100 \mu \mathrm{m} \text {.) Intermediate coat: gelled } \\
\text { bituminous solution - aluminium tinted } \\
\text { (min dft } 200 \mu \mathrm{m}) \text {. Topcoat: gelled } \\
\text { bituminous solution - black finish with } \\
\text { min dft } 200 \mu \mathrm{m} \text {. }\end{array}$ & $5-7$ \\
\hline M21 & $\begin{array}{l}\text { Coating using epoxy glass flake. First } \\
\text { layer: epoxy blast primer with min dft } \\
25 \mu \mathrm{m} \text {. Intermediate layer: epoxy glass } \\
\text { flake intermediate coat with min dft } 40 \mu \mathrm{m} \\
\text { and for layer C select among the } \\
\text { following (min dft } 50 \mu \mathrm{m}) \text { : anti-graffiti } \\
\text { paint or polyurethane-coloured finish or } \\
\text { acrylic urethane topcoat or polysiloxane } \\
\text { topcoat. }\end{array}$ & $18-22$ \\
\hline
\end{tabular}




\section{III-CALCULATIONS}

For original section without any corrosion loss values of bending moment and shear force capacity are as follows: Maximum Bending moment $=580.07 \mathrm{KN}-\mathrm{m}$

Maximum Shear force $=154.68 \mathrm{KN}$

Maximum deflection $=83.33 \mathrm{~mm}$

\begin{tabular}{|c|c|c|c|c|c|}
\hline \multirow[t]{2}{*}{$\begin{array}{l}\text { Sr. } \\
\text { no. }\end{array}$} & \multirow[t]{2}{*}{ Year } & \multirow[t]{2}{*}{$\begin{array}{l}\text { I axis } \\
(\mathrm{mm} 4) \\
\text { X } 106\end{array}$} & $\begin{array}{l}\text { Md Of Corroded } \\
\text { Section } \\
(\mathrm{KN}-\mathrm{m})\end{array}$ & $\begin{array}{l}\text { Vd Of Corroded } \\
\text { Section } \\
(\mathrm{KN})\end{array}$ & \\
\hline & & & $\mathrm{Md}=\left(ß b^{*} \mathrm{zp} * \mathrm{fy}\right) /{ }_{\gamma} \mathrm{mo}$ & $\begin{array}{c}\mathrm{Vd} \\
=(\mathrm{Av} * \mathrm{fy}) /(\sqrt{ } 3 * \mathrm{mo})\end{array}$ & $\begin{array}{c}\text { Actual } \\
\text { deflection }\end{array}$ \\
\hline 1 & 5 & 1559.5 & 958.2 & 860.5 & 43.5 \\
\hline 2 & 10 & 1524.6 & 937.3 & 827.6 & 44.5 \\
\hline 3 & 15 & 1491.9 & 917.6 & 796.7 & 45.5 \\
\hline 4 & 20 & 1460.3 & 898.6 & 767.0 & 46.5 \\
\hline 5 & 25 & 1429.6 & 880.1 & 738.0 & 47.5 \\
\hline 6 & 30 & 1399.4 & 861.8 & 709.5 & 48.5 \\
\hline 7 & 35 & 1369.6 & 843.9 & 681.4 & 49.6 \\
\hline 8 & 40 & 1340.1 & 826.1 & 653.7 & 50.7 \\
\hline 9 & 45 & 1311.0 & 808.5 & 626.2 & 51.8 \\
\hline 10 & 50 & 1282.1 & 791.0 & 598.9 & 53.0 \\
\hline 11 & 55 & 1253.4 & 773.6 & 571.8 & 54.2 \\
\hline 12 & 60 & 1224.8 & 756.3 & 544.9 & 55.4 \\
\hline 13 & 65 & 1384.9 & 853.1 & 695.9 & 56.8 \\
\hline 14 & 70 & 1371.1 & 844.8 & 682.8 & 58.1 \\
\hline 15 & 75 & 1357.4 & 836.5 & 669.9 & 59.6 \\
\hline 16 & 80 & 1343.8 & 828.3 & 657.1 & 61.1 \\
\hline 17 & 85 & 1330.4 & 820.5 & 644.5 & 62.7 \\
\hline 18 & 90 & 1317.1 & 812.1 & 631.9 & 64.3 \\
\hline 19 & 95 & 1312.1 & 809.2 & 627.3 & 66.0 \\
\hline 20 & 100 & 1299.0 & 801.2 & 614.9 & 67.9 \\
\hline 21 & 105 & 1286.0 & 793.3 & 602.6 & 69.8 \\
\hline 22 & 110 & 1281.4 & 790.5 & 598.2 & 71.8 \\
\hline 23 & 115 & 1268.5 & 782.7 & 586.1 & 74.0 \\
\hline 24 & 120 & 1255.7 & 775.0 & 574.0 & 76.3 \\
\hline
\end{tabular}

\subsection{Structural Capacities}

Table 5- Bending Moment And Shear Force Capacity Of Uncoated Steel Girder

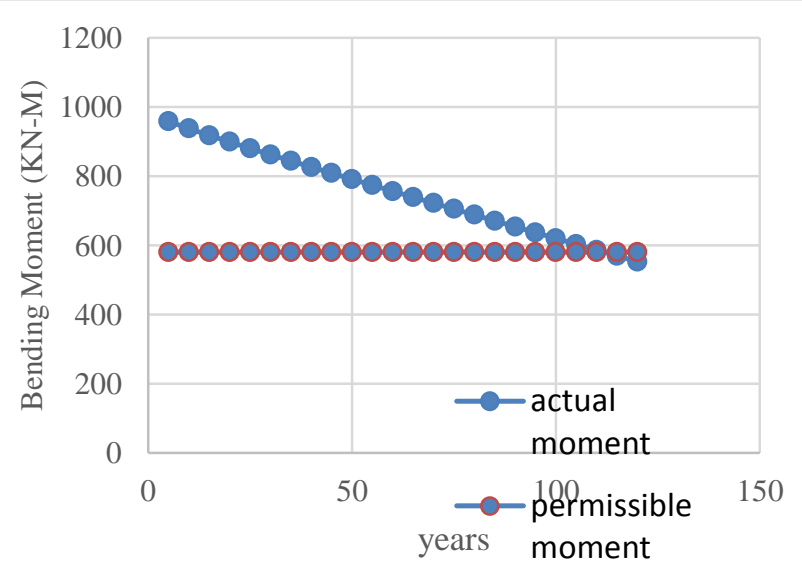

Fig no. 1 variation of bending moment of uncoated girder

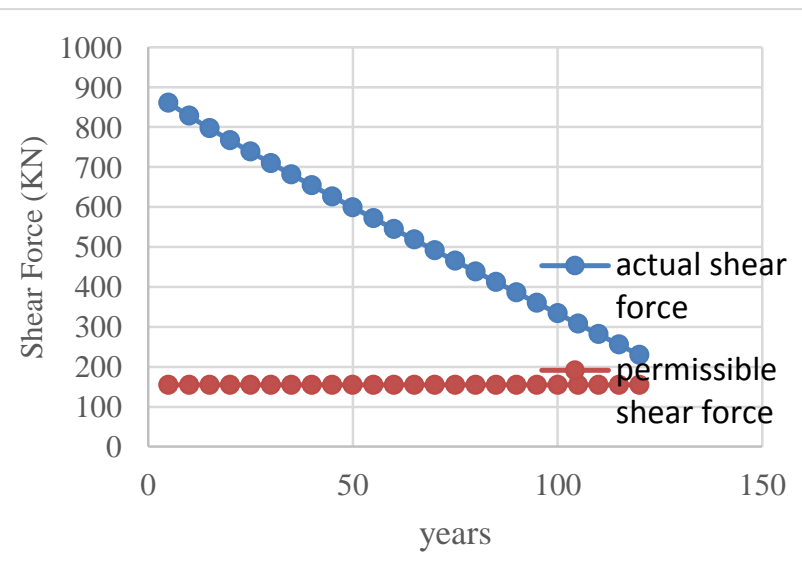

Fig no. 2variation of shear force of uncoated girder

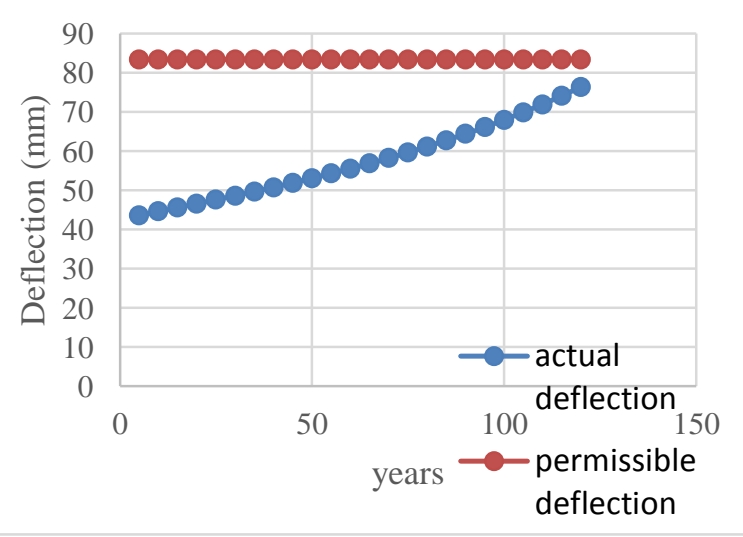

Fig no. 3 variation of deflection of uncoated girder 
Table no-. 6 Bending Moment And Shear Force Capacity Of Coated Steel Girder

\begin{tabular}{|c|c|c|c|c|c|}
\hline $\begin{array}{l}\text { Sr. } \\
\text { No. }\end{array}$ & Year & $\begin{array}{c}\text { I axis } \\
\left(\mathrm{mm}^{\wedge} 4\right) \\
\text { X } 106\end{array}$ & $\begin{array}{l}\text { Md Of Corroded } \\
\text { Section } \\
(\mathrm{KN}-\mathrm{m})\end{array}$ & $\begin{array}{l}\text { Vd Of Corroded } \\
\text { Section } \\
(\mathrm{KN})\end{array}$ & $\begin{array}{c}\text { Actual } \\
\text { deflection }\end{array}$ \\
\hline & & & $\mathrm{Md}=(ß \mathrm{~b} * \mathrm{zp} * \mathrm{fy}) / \gamma \mathrm{mo}$ & $\begin{array}{c}\mathrm{Vd} \\
=(\mathrm{Av} * \mathrm{fy}) /\left(\sqrt{ } 3 *{ }_{\gamma} \mathrm{mo}\right)\end{array}$ & \\
\hline 1 & 5 & 1582.1 & 971.8 & 881.7 & 42.9 \\
\hline 2 & 10 & 1554.2 & 955.1 & 855.5 & 43.7 \\
\hline 3 & 15 & 1533.0 & 942.3 & 835.4 & 44.3 \\
\hline 4 & 20 & 1514.3 & 931.1 & 817.8 & 44.8 \\
\hline 5 & 25 & 1496.9 & 920.6 & 801.5 & 45.4 \\
\hline 6 & 30 & 1488.7 & 915.7 & 793.7 & 45.6 \\
\hline 7 & 35 & 1472.8 & 906.1 & 778.8 & 46.1 \\
\hline 8 & 40 & 1457.4 & 896.8 & 764.2 & 46.6 \\
\hline 9 & 45 & 1442.4 & 887.8 & 750.1 & 47.1 \\
\hline 10 & 50 & 1427.7 & 878.9 & 736.2 & 47.6 \\
\hline 11 & 55 & 1413.2 & 870.2 & 722.6 & 48.1 \\
\hline 12 & 60 & 1399.0 & 861.6 & 709.1 & 48.5 \\
\hline 13 & 65 & 1384.9 & 853.1 & 695.9 & 49.0 \\
\hline 14 & 70 & 1371.1 & 844.8 & 682.8 & 49.5 \\
\hline 15 & 75 & 1357.4 & 836.5 & 669.9 & 50.0 \\
\hline 16 & 80 & 1343.8 & 828.3 & 657.1 & 50.5 \\
\hline 17 & 85 & 1330.4 & 820.2 & 644.5 & 51.0 \\
\hline 18 & 90 & 1317.1 & 812.1 & 631.9 & 51.6 \\
\hline 19 & 95 & 1312.1 & 809.2 & 627.3 & 51.8 \\
\hline 20 & 100 & 1299.0 & 801.2 & 614.9 & 52.3 \\
\hline 21 & 105 & 1286.0 & 793.3 & 602.6 & 52.8 \\
\hline 22 & 110 & 1281.4 & 790.5 & 598.2 & 53.0 \\
\hline 23 & 115 & 1268.5 & 782.7 & 586.1 & 53.5 \\
\hline 24 & 120 & 1255.7 & 775.0 & 574.0 & 54.1 \\
\hline
\end{tabular}

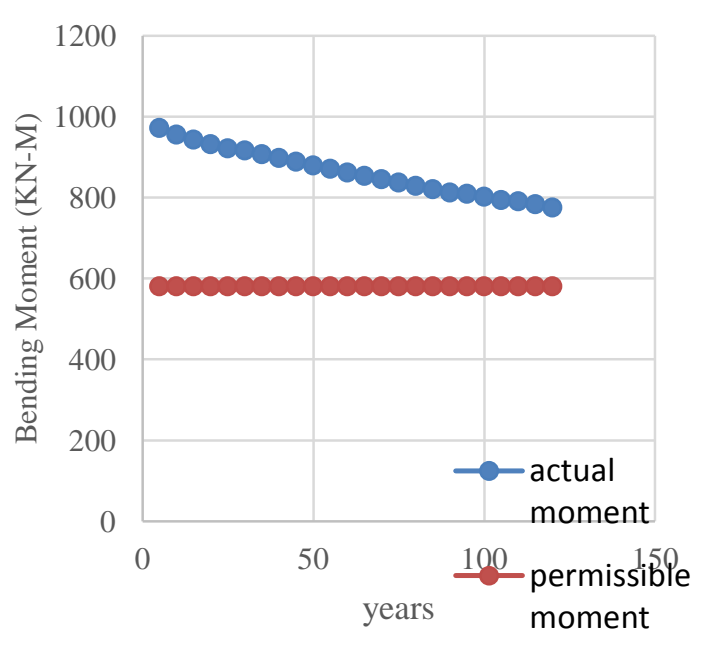

Fig no. 4 variation of bending moment of coated girder

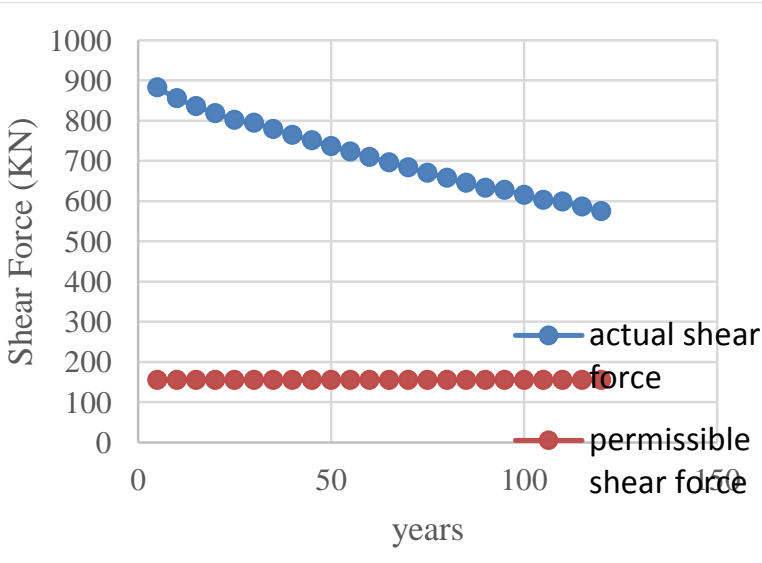

Fig no. 5 variation of shear force of coated girder

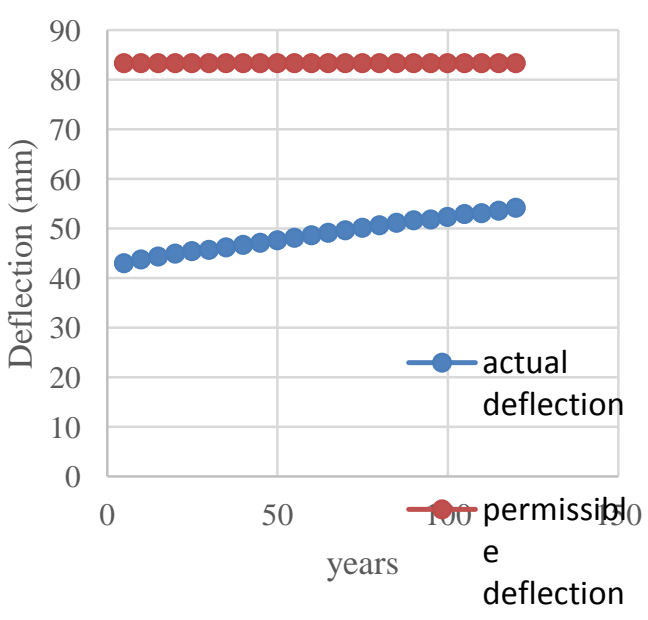

Fig no. 6 variation of deflection of coated girder 


\section{IV-RESULT}

\section{Bending Moment}

Moment of resistance of girder is decreasing with increasing girder age. But in the fig. 1 of an uncoated girder, the value of bending moment is decreasing in such a way that, after 100th year or at 120th year, actual moment line is crossing the permissible moment line. It means that the girder will fail at that year in the resisting bending moment and it will become incapacitated to take any further bending moment. Hence it will not be safe to use that bridge after that age for day to day life.

Fig.4 indicates coated girder can take up more bending moment where uncoated girder fails and it will remain useful for a much longer period than uncoated one.

\section{Shear Capacity}

Fig. 2 of uncoated girder indicate that section has reached near the failure line just after 100th year and soon it is going to cross the permissible value of shearing resistance. While in the case of coated girder $i$. e. fig. 5, there are so many years left for the structure to reach its permissible value.

\section{Deflection}

Fig. 3 shows that, due to corrosion, actual deflection line after $100^{\text {th }}$ year is very close to the permissible deflection line. In case of coated condition fig, 6, the actual deflection line still has to go through a lot deflection to reach permissible deflection line.

Table no. ----- Performance of girder of size 740 x 250 at age of 120 years

\begin{tabular}{|c|c|c|c|c|c|c|}
\hline \multirow{2}{*}{$\begin{array}{l}\text { Design } \\
\text { parameter }\end{array}$} & \multicolumn{2}{|c|}{ Bending Moment(KN-m) } & \multicolumn{2}{c|}{ Shear force (KN-m) } & \multicolumn{2}{c|}{ Deflection(mm) } \\
\cline { 2 - 7 } & actual & permissible & actual & permissible & actual & permissible \\
\hline Uncoated & 552.71 (fail) & 580.02 & 229.46 & 154.68 & 76.31 & 83.33 \\
\hline coated & 775.05 & 580.07 & 574.06 & 154.68 & 54.13 & 83.33 \\
\hline
\end{tabular}

\section{V- CONCLUSION}

The main cause of bridge deterioration is repeated vehicular loads and adverse environmental exposure. The most dominant deterioration form for steel bridge is corrosion which is characterized by the loss of metal area resulting in reduction of structural capacity. At times, the rust is serious enough to disconnect the web from the flanges of girder. This research investigates the structural capacity of these corroded steel girders. We conclude that as the corrosion increases, BM and SF will decrease and it will result in lowering the load carriying capacity of the structure. Due to corrosive action, moment of resistance of the section is greatly affected than shear resistance of section. By analyzing graph and data we can predict that at what year section is going to fail, according to that, we can take the necessary preventive measures by repairing the bridge before the failure. It will save the damages and the lives of many. Repairing the bridge will always be economical than constructing a new one.

1. Result shows that, the bending moment of uncoated girder is $552.71 \mathrm{KN}-\mathrm{m}$ while bending moment of coated girder is $775.04 \mathrm{KN}-\mathrm{m}$. Therefore it concludes that we can use paint $\&$ other anti-corrosive chemical agent to increase lifespan of girder bridge.

2. As the area loss due to corrosion increase then the load carrying capacity of structure will decrease.

3. The bending moment resistance of the girder is largely reduced as compared to its shear resistance due to corrosion.

4. Analytical results show that section need to be repair after 95-100 years of life span.

5. If the accumulating damage cannot be timely detected, the structural safety will be threatened and the damage may finally cause the partial or whole collapse of the structure, resulting in economic lose and faculty casualty.

\section{REFERENCES}

[1] Reliability of corroded steel girder bridges - department of civil engineering, university of Michigan, Ann Arbor, MI 48109 (U.S.A.)

[2] Kinetics of atmospheric corrosion of mild steel, zinc, galvanized iron \& aluminium at 10 exposure stations in India - www.sciencedirect.com 
International Journal of Innovations in Engineering and Science, Vol 5, No.7, 2020

\section{$w w w . i j i e s . n e t$}

[3] Evaluation of atmospheric corrosion damage to steel space structures in coastal areas www.sciencedirect.com

[4] Life-cycle cost comparison of corrosion management strategies for steel bridges - ascelibrary.org by lowa state university

[5] Structural capacity analysis of corroded steel girder bridges - civil engineering technology, college of applied science and technology, Rochester institute of technologyaxbite@rit.edu

[6] Performance profiles of metallic bridges subject to coating degradation and atmospheric corrosion http://www.tandfonline.com/loi/nsie20 